\title{
Special issue on artificial intelligence and machine learning for real-time image processing
}

\section{S. Balamurugan ${ }^{1}$}

Published online: 30 July 2021

○) Springer-Verlag GmbH Germany, part of Springer Nature 2021

Publisher's Note Springer Nature remains neutral with regard to jurisdictional claims in published maps and institutional affiliations.

S. Balamurugan

sbnbala@gmail.com

1 Albert Einstein Engineering and Research Labs (AEER

Labs), Coimbatore, Tamil Nadu, India 